\section{artelogie}

\section{Artelogie}

Recherche sur les arts, le patrimoine et la littérature de l'Amérique latine

15 | 2020

Latin American networks: Synchronicities, Contacts and Divergences.

\title{
The Brazilian Cultural Mission and the Arte Nuevo Group: A Regional Dispute for Cultural Hegemony and Paraguayan Modern Art
}

\section{Charles Quevedo.}

Translator. George Flaherty, Andrea Giunta and Jane Brodie

\section{(2) OpenEdition}

\section{Journals}

Electronic version

URL: http://journals.openedition.org/artelogie/4582

DOI: $10.4000 /$ artelogie.4582

ISSN: 2115-6395

\section{Publisher}

Association ESCAL

Electronic reference

Charles Quevedo., «The Brazilian Cultural Mission and the Arte Nuevo Group: A Regional Dispute for Cultural Hegemony and Paraguayan Modern Art », Artelogie [Online], 15 | 2020, Online since 17 April 2020, connection on 06 August 2020. URL : http://journals.openedition.org/artelogie/4582 ; DOI : https://doi.org/10.4000/artelogie.4582

This text was automatically generated on 6 August 2020 .

Association ESCAL 


\section{The Brazilian Cultural Mission and the Arte Nuevo Group: A Regional Dispute for Cultural Hegemony and Paraguayan Modern Art}

\section{Charles Quevedo.}

Translation : George Flaherty, Andrea Giunta and Jane Brodie

\section{Introduction}

1 Though signs of change first began to appear in Paraguayan art in the nineteentwenties, it was not until the fifties that they sunk in. This essay will reexamine those initial attempts and analyze the context that enabled the consolidation of modern art in Paraguay, which is historically enmeshed in that country's cultural relations with Brazil.

2 In April 1920, after a twelve-year absence from Asunción, Andrés Campos Cervera (1888-1937)-generally considered Paraguay's first modern artist-exhibited at the Salón de Belvedere. The artist, who was later known as Julian de la Herrería, showed several works he had made during his European sojourn, spent mostly in Madrid and Paris, as well as a series of works with Senegalese motifs painted during a short stay in Dakar. Among the artworks on display were paintings with an unquestionable Fauvist bend, a visual language unknown to a local scene characterized by isolation from international trends. The exhibition "made a deep impression on a milieu accustomed to seeing the landscape through the old academic and picturesque conventions" (Plá, n.d.: 116). Though jarring, the show was a relative success economically (a number of the works were sold). His later work, most of it ceramics, would engage indigenous iconography or rural scenes in a dialogue with local and popular traditions (Rodríguez-Alcalá, 2010). 
3 The work of Jaime Bestard (1892-1965) and of Ofelia Echagüe Vera (1904-1987) can be placed within the framework that prevailed in the Rio de la Plata between in the twenties, thirties, and forties, a context tied to the "Return to Order." Bestard attempted to restore the figurative image in Paraguayan art while incorporating elements of post-cubist abstraction, purism, and metaphysical painting and reinterpreting classic early-Italian models (López Anaya, 1997). Starting in the thirties, Ignacio Núñez Soler (1891-1983) worked on images of the Asunción of times past, addressing with a measure of nostalgia the "progress"-political events and popular celebrations, for instance-that had erased a certain urban space. For Núñez Soler urban identity means salvaging from oblivion. Though arguably academic, his work elaborated a very distinctive version of "naive art" (Rodríguez-Alcalá, 2010).

4 This foundational phase of Paraguayan modern art, which began in the twenties and continued into the fifties, brought autonomy as forms were released from their previous "descriptive" function (Rodríguez-Alcalá, 2010). During this period, Paraguayan modernism, like all Latin American modernisms, addressed at once questions of formal renovation (rupture) and the urgent search for identity part and parcel of the rise of the modern city underway at that time. In Paraguay, this process was fragmented and scattered; modernism in art was not articulated collectively or programmatically (Rodríguez-Alcalá, 2010).

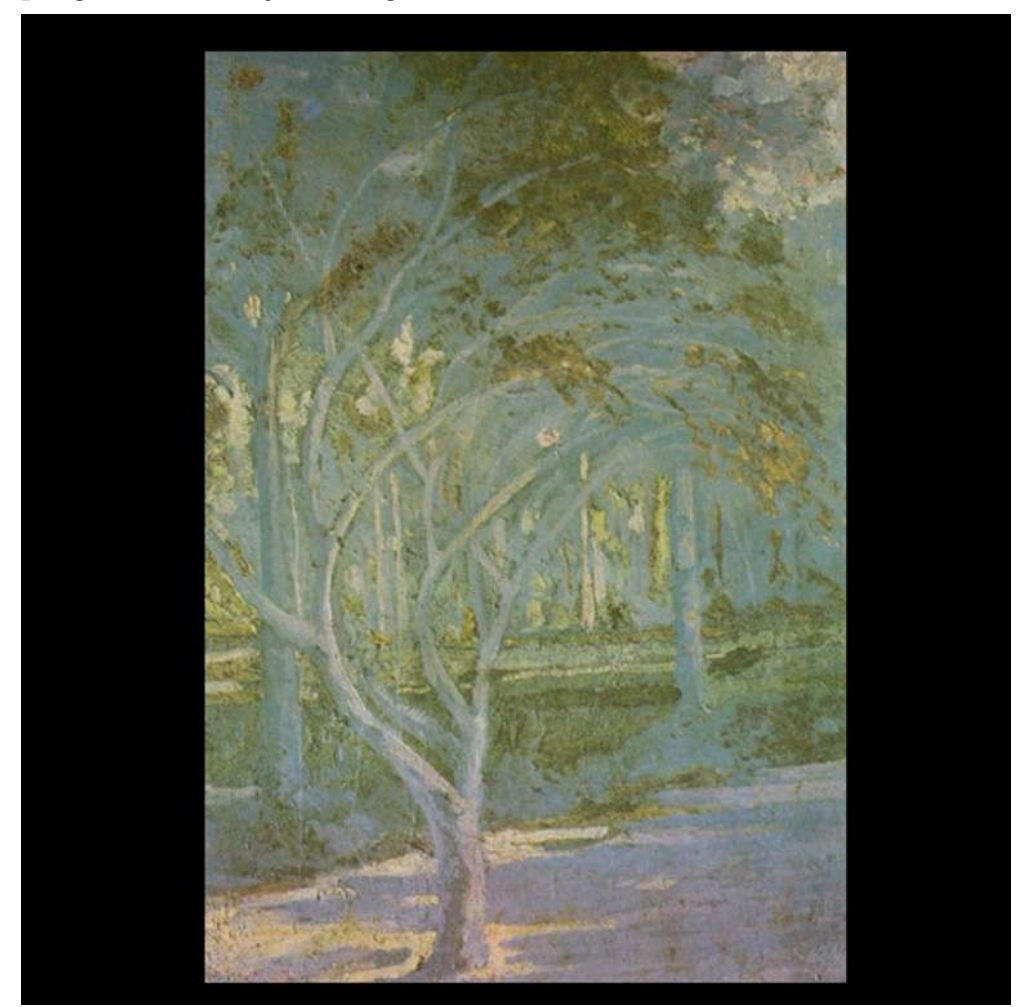

Figure 1: Julián de la Herrería, Árboles color malva (Mauve-colored Trees), 38 × 53 cm, 1928 


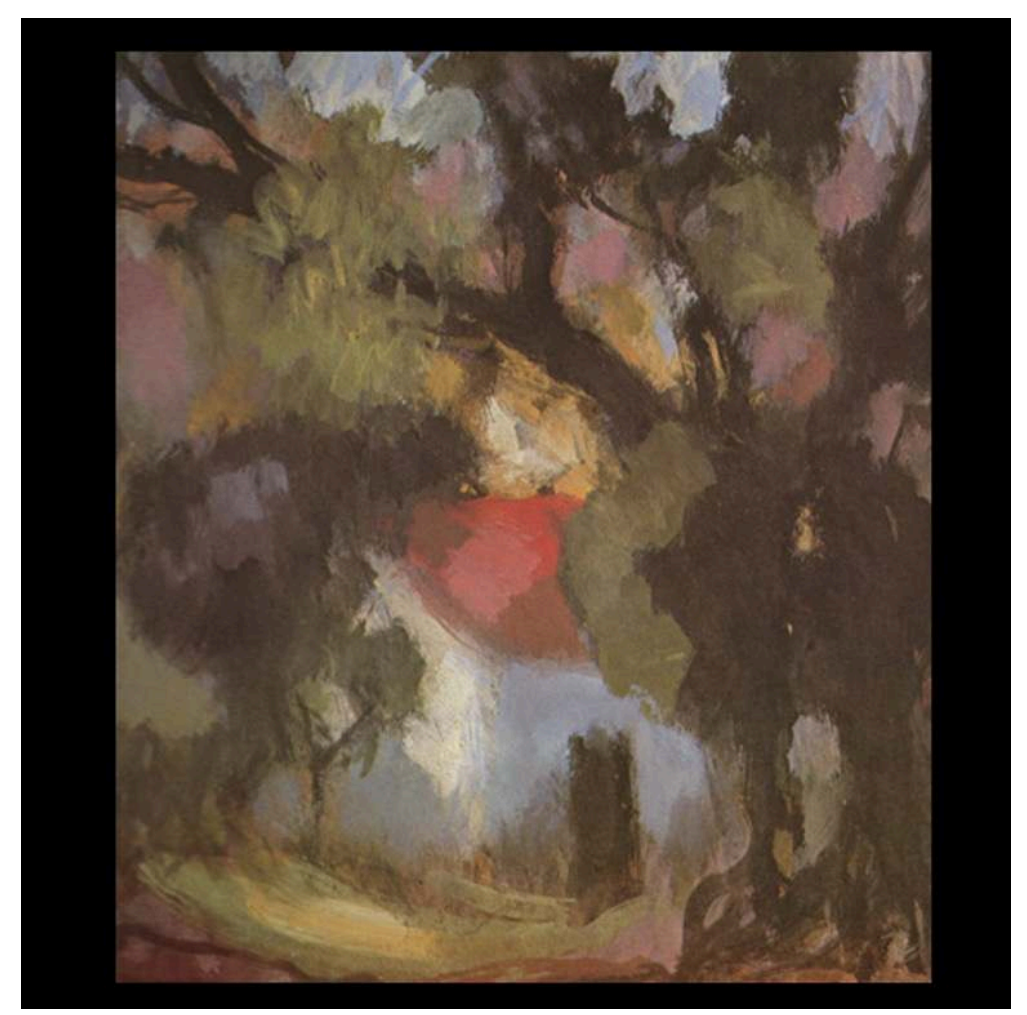

Figure 2: Jaime Bestard, Rancho con árboles (Ranch with trees), oil on wood, 30 × 30 cm, ca.1940. Jorge Gross Brown Collection.

5 The second moment of Paraguayan modernism began with the First Week of Paraguayan Modern Art, which took place in July 1954. With it, the Arte Nuevo group emerged (Josefina Plá (1903-1999), Olga Blinder (1921-2008), Lilí Del Mónico (1910-2002), and José Laterza Parodi (1915-1981) were its core members). This was, to a certain extent, a moment of "avant-garde activism," insofar as the modern was championed in "political-pedagogical" terms. Though difficult to characterize because heterogeneous, the Nuevo Arte group's proposal addressed issues that had surfaced in the twenties and thirties, that is, during the first phase of modernism. Central to the group's vision was a strain of social realism with an expressionistic bend, Mexican muralism, the work of Candido Portinari, a certain cubist-constructivist geometrization, and stylization that would eventually lead to non-figuration (Rodríguez-Alcalá, 2010). The importance of the Arte Nuevo group in the fifties wouldas Escobar argues (2007) - not be based on a cohesive and clear agenda but rather on its strategic position and its capacity to bring together scattered attempts at experimentation, to mobilize aesthetic possibilities, and to create a climate of renewal.

6 Though it aspired to bring about thorough-going change in the history of Paraguayan art-explicitly and collectively expounding its determination to renovate-the Arte Nuevo group was in fact largely a re-reading and extension of the first modern Paraguayan experiences. Ceramics by Josefina Plá and Laterza Parodi took up the forms Julián de la Herrería had created in the thirties, bringing to bear on them contemporary ideas developed in new territories like the international exhibitions and biennials that Paraguay would begin to participate in. This could be seen as what Hal Foster (2001) calls a recovery, a reconnection with a past practice that implies at once disconnection from a current practice and the development of a new one. 
7 Paradoxically, the discourse of rupture at the core of the Arte Nuevo group's practices was coupled with frequent reference to a genealogy that goes back to Julián de la Herrería. Works made in the thirties by an artist who had not been heard from for over a decade were exhibited locally and internationally alongside those by members of the group. De la Herrería was a constant presence and object of reverence throughout these years. The collective print workshop founded by Livio Abramo in 1956 was called the Taller de Grabado Julián de la Herrería. An article published in the Asuncion newspaper La Tribuna in July 1957 reports on an exhibition of modern art in the halls of the Paraguay-Brazil Cultural Institute in his honor. Furthermore, the opening of the First Week of Paraguayan Modern Art coincided with the $17^{\text {th }}$ anniversary of de la Herrería's death in a clear attempt to establish him as a founding father of Paraguayan modernism. In 1954, art critic Miguel Ángel Fernández, who was very close to the Arte Nuevo group, wrote of de la Herrería:

"Classical" means "exemplary," and his work is indeed exemplary. His example continues to spread: enthusiastic disciples are picking up on the many paths his work opened up. Today, with more fervor than ever, they are heading down the high roads of America (1954: 5).

8 By "enthusiastic disciples," the ones exploring "the many paths" of de la Herrería's work, Fernandez was undoubtedly referring to the Arte Nuevo group. It embraced the power of his vision but then updated it. Paraguayan art history may have placed too much emphasis on the component of rupture in the Arte Nuevo group's practices on the basis of a certain reading of the thinking of the group's main theorists (Ramiro Domínguez, Josefina Plá, and olga Blinder). The continuities, the sense of a single process unfolding in a plethora of approaches that run through history, may have been obscured. The First Week of Paraguayan Modern Art was almost a performative act, an outgrowth of the discourse of the advocates of incipient modern art. It brought into the present the impulses and powers at play in the initial modern moment. The correspondence between the Arte Nuevo group and early modernism is, arguably, a case of Hal Foster's reworking of the Freudian concept of "deferred action." Foster holds that an event only comes to fruition when recoded in another event that explains it. According to Foster:

The historical avant-garde and the neo-avant-garde are constituted in a similar way as a continuous process of protension and retention, a complex relay of anticipated futures and reconstructed pasts-in short, a deferred action that throws over any simple scheme of before and after scheme, cause and effect, origin and repetition (2001: 31)

9 No less significant in critic Miguel Ángel Fernández's words is the objective of taking Julián de la Herrería's contributions to "the high roads of America." In fact, a central concern of the Arte Nuevo group was to gain visibility in Latin American artistic circuits, to internationalize, which largely meant, at that time, to break out of artistic isolation (Giunta, 2004). The strategic internationalism of Brazilian modernism, starting with the creation of modern art museums in São Paulo (MAM-SP) and in Rio de Janeiro and, in the early fifties, of the São Paulo Biennial, put on the agenda of Latin American art the need to break out of isolation and to venture into new circuits in search of recognition. The Arte Nuevo group resolutely pursued taking Paraguayan art into those new circuits and gaining recognition on them. At the same time, the group took on the task of "updating Paraguayan art," understood at the time to mean raising up "backward" art, bringing it up to international levels and standards. An article 
published in Asunción under the title "The Exhibition on Palma Street" illustrates this very well:

The exhibition of paintings and ceramics to open today will be displayed in the shop windows of various commercial establishments on Palma Street. It will showcase modern art, a trend that must prevail if we are to reach the artistic level of the most advanced countries, which have taken a leap forward in the field of art and culture. (1954: 6)

11 From the time of its founding in the mid-fifties and through the early sixties, the Arte Nuevo group relentlessly pursued the goal of "internationalizing" Paraguayan art. Its main contribution was to insert Paraguayan modern art in the regional space. That aim was furthered by the strategies deployed by Brazilian cultural diplomacy in Paraguayin a context of vying with Argentina for regional hegemony-and by a concurrent reorientation of Paraguayan foreign policy by the Stroessner regime.

12 I will now turn to the conditions of possibility that enabled Paraguayan modern art's incursion into the regional space. With neither substantial private-sector support of the sort provided by the Brazilian industrial bourgeoisie in the forties or the public cultural policies of the sort pursued by Brazil starting in 1940 and by Argentina after 1955, Paraguay found other ways to bolster its modern art and to modernize its art institutions. My hypothesis here is that various projects (Brazilian cultural diplomacy in a context of regional competition over hegemony; a new turn in Paraguayan foreign policy) and actors (artists' collectives, critics, Paraguayan and Brazilian cultural managers) were able to overcome existing antagonisms. Thanks to unifying strategies deployed at a specific moment, it was possible to bring Paraguayan modern art onto the regional space as a palpable presence. ${ }^{1}$

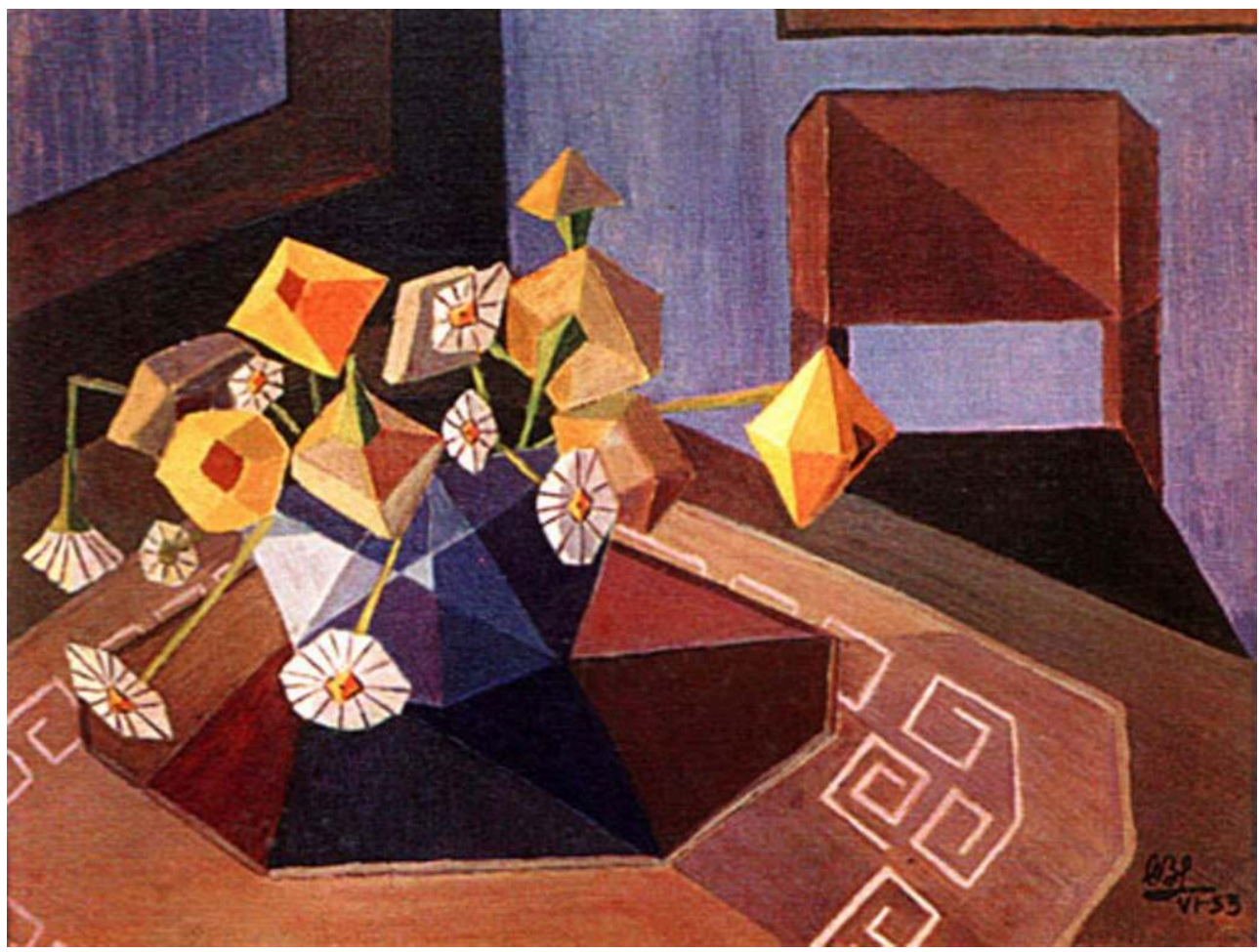

Figure 3: Olga Blinder, Naturaleza muerta (Still Life), oil on canvas, $40 \times 50 \mathrm{~cm}$, 1953. Roberto Ugarte Collection 


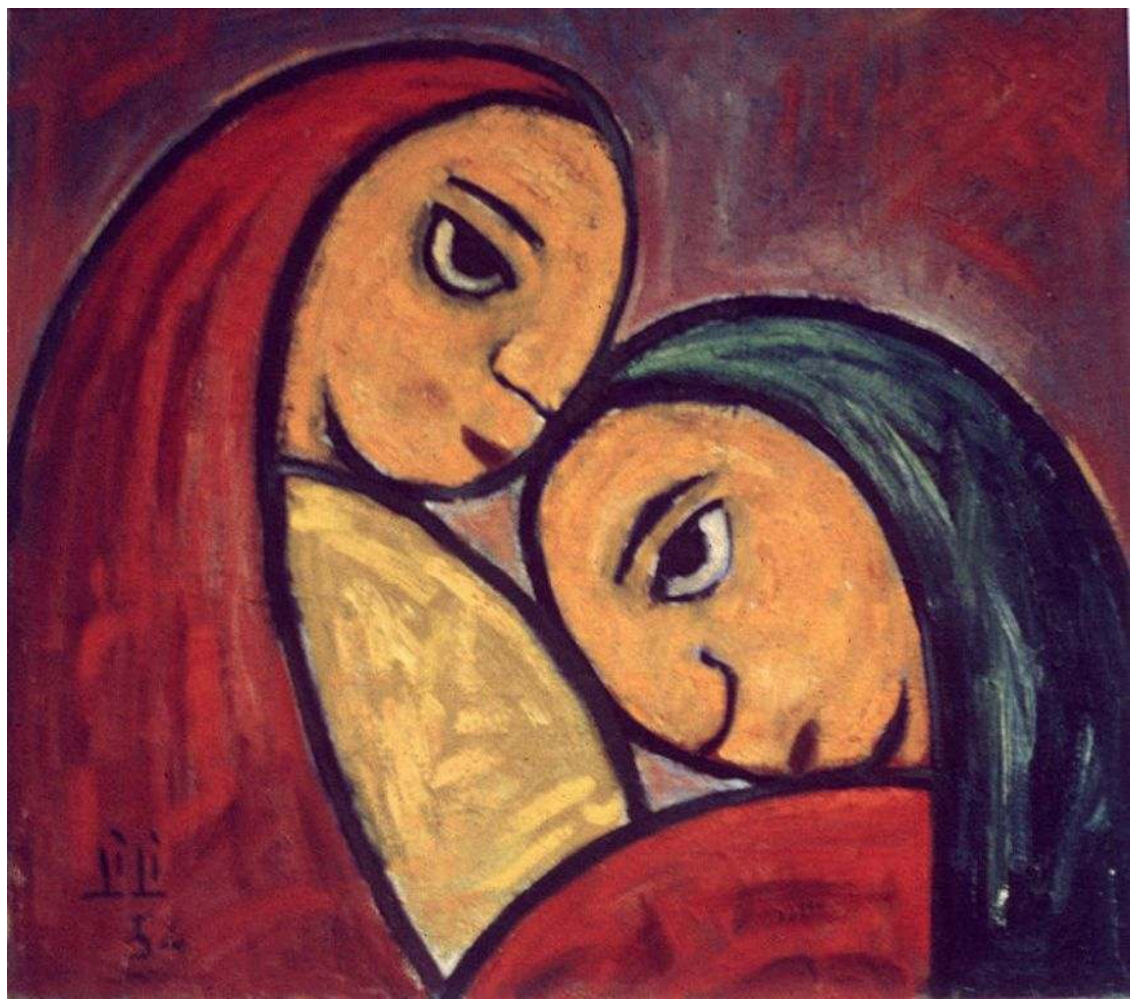

Figure 4: Lilí Del Mónico, Figuras (Figures), oil on canvas, 45 x 48 cm, 1954. CAV/Mud Museum

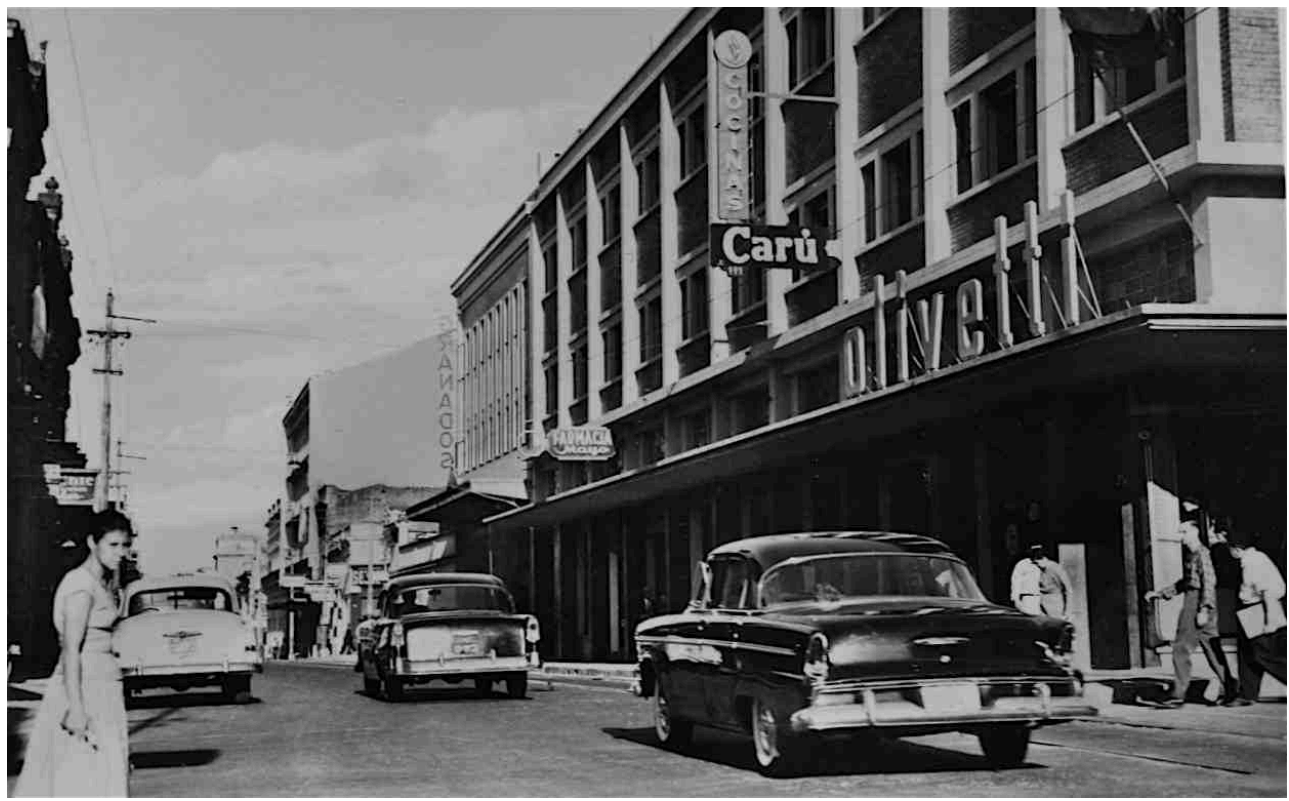

Figure 5: Downtown Asunción around the fifties, Klaus Henning, untitled, ca. 1950 Henning Family Archive

\section{Disputes over Regional Hegemony}

Starting in the thirties, diplomatic relations between Brazil and Argentina were increasingly tense. Brazil perceived Argentina as aggressive and expansionist. It believed its neighbor to the south was seeking to isolate it in pursuit of continental 
hegemony. Each country took its own-and manifestly antagonistic to the otherstance on foreign policy in the forties. During World War II, Brazil declared war on the Axis and signed economic and political-military agreements with the United States. Argentina bet on neutrality, which the Allies saw as an unwillingness to join the global crusade against fascism. Despite frequent statements of intent to keep the peace, military activity increased on both sides of the border between Argentina and Brazil (García, 2011).

14 These divergent positions brought not only political-economic disputes, but also tensions in the cultural sphere. From 1947 to 1949, three art museums were created in São Paulo and Rio de Janeiro, and the São Paulo Biennial was founded; Brazil and its elites had put in place a formidable cultural bureaucracy. Through these cultural efforts, the Brazilian state asserted itself as a progressive player, and the country as a new artistic hub in an open bid for the cultural hegemony Argentina had enjoyed in the past.

15 In 1947, the Museu de Arte de São Paulo (MASP) opened its doors, and the following year the Museu de Arte Moderna (MAM-SP) did the same. Those institutions, along with the Museu de Arte Moderna de Rio de Janeiro (MAM-RJ), would be key to shaping the cultural agenda of the forties and the future of art in the region. Through these cultural endeavours, emerging industrial sectors and the new industrial bourgeoisie in São Paulo sought to move beyond the strictly economic sphere. It was through the museums of modern art-temples to the religion of modernization-that São Paulo in particular lay claim to cultural hegemony, challenging Buenos Aires. The Brazilian response of the Venice Biennale, the São Paulo Biennial was an optimal way to make the country's newfound power visible and to show it to be the most prosperous Latin American city in the postwar period. The absence of Argentine representation at the First São Paulo Biennial (1951) was a clear symptom of the tensions between the two countries at that time (Garcia, 2011).

16 Throughout the nineteenth and twentieth centuries, Paraguay was an object of dispute between Argentina and Brazil. With its defeat in the War of the Triple Alliance (1864-1870), Paraguay became a de facto dependent of Argentina's, its port and cities. The elites of Asunción turned toward Buenos Aires culture. By the end of the nineteenth century, it was common for Paraguayan elites to complete their higher education in Argentina. Teachers received scholarships to further their studies in the Argentine province of Entre Ríos, and military officers went to the military college in Buenos Aires. Asunción's upper classes were thrilled by the proximity of Buenos Aires, the metropolis to the south (Capdevila, 2010). Throughout what is called the liberal era in Paraguay (1904-1940), Argentina was the most important foreign actor (Mora, 1993).

In the forties, Brazilian President Getulio Vargas supported a series of actions designed to confront Argentine hegemony. In 1941, he visited Asunción to create a base of operations. Brazil began offering Paraguayans scholarships to study in its territory, and economic, cultural, and military cooperation agreements were signed between the two countries, including one that made Santos a free trade zone. Despite Brazil's efforts, Paraguayan foreign policy from 1946 to 1954 still favored Argentina under Perón, though it did maintain cordial relations with Brazil and the United States (Mora, 1993). When General Alfredo Stroessner took power in 1954, Paraguayan foreign policy would change direction, and Argentine influence would begin to diminish. To neutralize the traditional Argentine presence and to manipulate the regional balance of power to his 
advantage, Stroessner strengthened ties to Brazil. He began to look eastward for a new trade route. Brazil, meanwhile, had spent an entire decade trying to increase its influence in the region, providing aid to "client" nations such as Paraguay, Uruguay, and Bolivia. Brazil was ultimately aiming to become South America's hegemonic power (Mora, 1993).

Decree No. 7712, signed by Getulio Vargas in August 1941 and later by Paraguayan President Higinio Morínigo, established a framework for exchange between the two nations in, among other areas, education, laying the groundwork for a vast program of cultural diplomacy that would be known as the Brazilian Cultural Mission. (Cintra Nepomuceno, 2010)

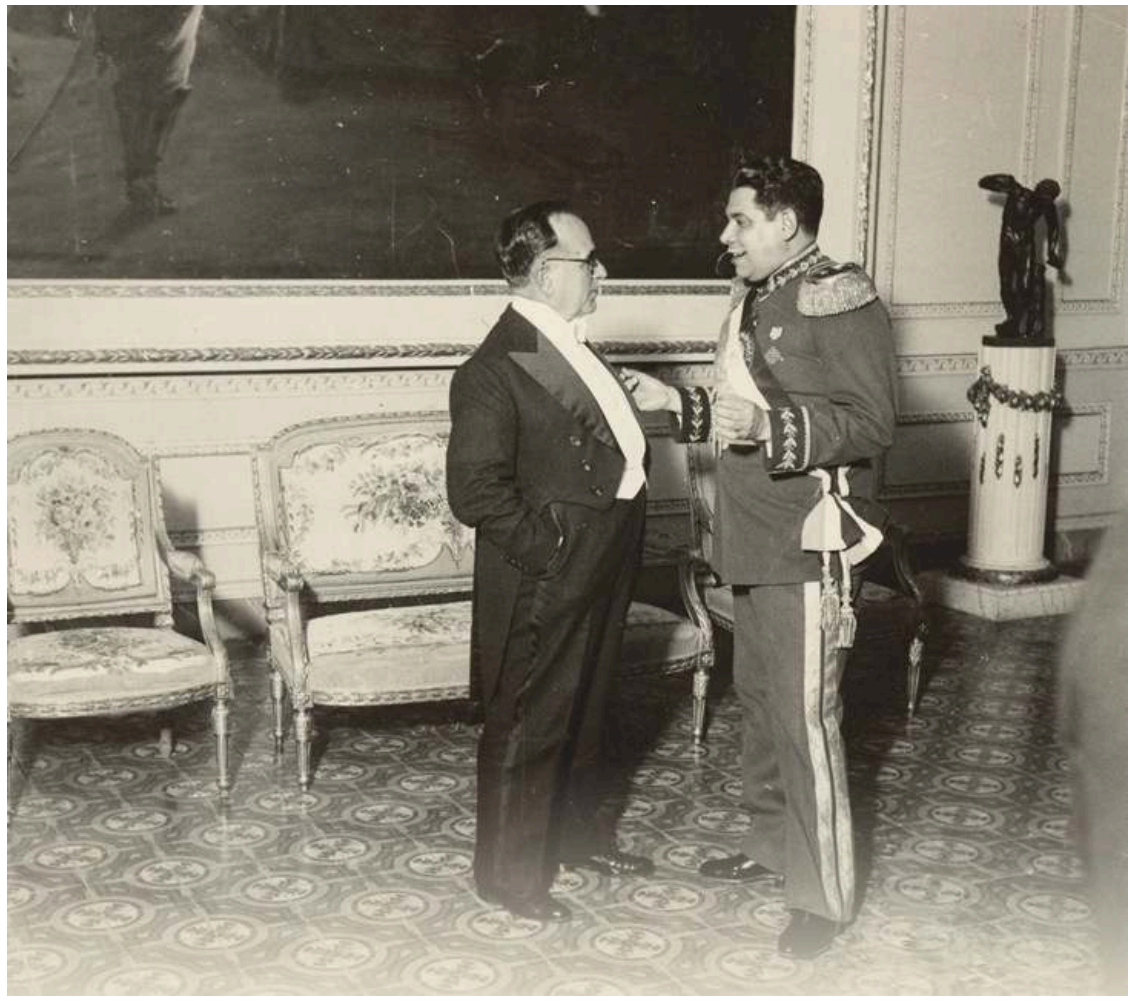

Figure 6: Getúlio Vargas with Higínio Morínigo, Asunción, 1941.

\section{Making a Mark on the Paraguayan Soul: The Brazilian Cultural Mission}

The Brazilian Cultural Mission (MCB) in Asunción (launched gradually, from 1941 to 1944), along with the Mission in Montevideo (launched in 1940), was one of the first programs the Cultural Department of the Ministry of Foreign Affairs of Brazil, or Itamaraty, implemented in the region (Cintra Nepomuceno , 2001). In 1942, the BrazilParaguay Institute was created in Rio de Janeiro. The following year, its counterpart, the Paraguay-Brazil Institute, opened in Asunción. Brazilian historian Guy de Holanda, a member of the Institute, along with Paraguayan professors Hermogenes Rojas Silva, Mariano Morínigo, and Osvaldo Chaves were the ones who founded the School of Humanities, which would later, in 1948, become the Universidad Nacional de Asunción School of Philosophy. 
20 It was not, officially, until March 1952 that the educational and cultural programs enacted in Paraguay were brought together as the Brazilian Cultural Mission. The Mission's actions in culture initially revolved around teaching Portuguese language and literature, though there were also exchanges between professionals in technical and educational areas. A great deal of the Mission's effort was geared to the School of Philosophy, since those involved in it were drawn from the intellectual elite key to spreading the pro-Brazil message. Essential to understanding the nature of the Brazilian Cultural Mission is a paragraph, cited by Reiter Chedid, from a confidential report sent to the Itamaraty Cultural Division in 1953:

Our work, which encompasses elementary school, high school, and higher education, will leave its mark on the Paraguayan soul. If we continue to work in this direction, much of the local elite will, in a few year's time, have been drawn in to and identify with Brazil. (Apud Reiter Chedid, 2010: 71)

21 The Brazilian strategy sought to modify relations between the two countries through active intervention in the Paraguayan cultural field. In many documents submitted by the Mission to Itamaraty, like the one above, the need to influence Paraguayan political and intellectual elites is clearly stated. The initial aim was to pave the way for a Brazilian incursion into Paraguay and the ultimate goal to replace Argentina as the dominant influence.

As part of that strategy, the Brazilian Cultural Mission approached the most prestigious cultural and intellectual circles in Asunción through the School of Philosophy and the Paraguay-Brazil Cultural Institute. Cintra Nepomuceno (2010) points out that the Mission's work went beyond those first courses in Portuguese language and literature. Starting in the fifties, the Institute enacted a broad and diversified agenda of cultural diplomacy, working its way into the country's cultural community.

The first exhibition of photography organized by the Cultural Mission at the headquarters of the Paraguay-Brazil Cultural Institute featured works by Brazilian sculptor Antonio Francisco Lisboa (known as Aleijadinho). An important event, the exhibition, which opened in October 1953, included two hundred and eighty photographs of Aleijadinho's religious works from the collection of the Cultural Division of the Brazilian Ministry of Foreign Affairs. The exhibition was organized by Lygia Martins Costa from the Museu Nacional de Belas Artes in Rio de Janeiro. The unsigned article "Exhibition Opens" published in La Tribuna newspaper reports that, according to Albino Peixoto, the head of the Cultural Mission, the exhibition would be the first in a series on modern architecture and painting. A number of Paraguayan government officials were at the opening, among them the Minister of Education, Dr. Juan Ramón Chaves, who "made brief remarks on the cultural exchange between the two countries, which has been actively pursued by both parties" (La Tribuna,1953:5). That same month, Argentine President Juan Domingo Perón visited Asunción to meet Federico Chaves, president of Paraguay. The visit, which was an important episode in Argentine-Paraguayan relations, included the signing of agreements to accelerate a plan for the economic integration of the two countries (Mora, 1993). The press of the time reports that Albino Peixoto, the head of the Cultural Mission, was an active presence in the Asunción cultural community. He frequented groups like the Centro de Artistas Plásticos del Paraguay (CAPP) and the Asociación Amigos del Arte which, along with the Centro Paraguayo-Americano and the Casa Argentina, were venues where art activities took place (not only exhibitions, but also courses, lectures, 
competitions, and others). A sharp turn toward Brazilian culture on the part of certain factions of the intellectual and artistic elites was clearly underway. Particularly interesting is Josefina Plá's growing ties to the Brazilian artistic circuits thanks to the Cultural Mission. Josefina Plá would become one of the main advocates and theorists of the Arte Nuevo group. ${ }^{2}$

Between January and March 1953, La Tribuna published several articles by Josefina Plá on Brazilian culture. In January, she wrote a review of Paraguayan Poetry: History of a Mystery, a book by Brazilian writer and critic Walter Wey, a member of the Brazilian Cultural Mission. Plá describes the book, published in Montevideo in 1951, as an important point of reference for Paraguayan literature. In subsequent articles published in March of that year-namely, "Interpreting Brazil," "Brazilian Folk Dances," and "Orpheus Invention"-she offers a penetrating analysis of various aspects of Brazilian culture. The texts evidence determination to pursue in-depth understanding of the culture of a country with significant weight in Paraguay (Cintra Nepomuceno, 2010). The same year, at the invitation of the Cultural Mission, Josefina Plá delivered a lecture on "The Personality of Brazilian Doctor and Poet Jorge Lima" at the School of Philosophy as part of a series of lectures on historical and cultural issues (other lectures were given by Paraguayans Dr. Vicente Ramírez, Miguel Solano López, and Antonio Ramos, and by Brazilians Lygia Martins Costa, Ary da Matta, and Roberto Peixoto). Josefina Plá's interventions were unquestionably a way to reciprocate the recent interest in Paraguayan culture and artists shown by Brazil. They were also part of the process of forging relations with Brazilian cultural circuits, relations that would prove decisive to the Arte Nuevo group's insertion in regional modern art. These exchanges also included Plá's participation in the VI Salão de artistas plásticos in Rio de Janeiro in 1952, and the review of that salon published by Romanian-Brazilian critic Stefan Baciú ("Josefina Plá. Mulher de sete instruments." Note in Letras e tendencias actuais na literatura paraguaia, Rio de Janeiro, 1952).

Brazil's powerful cultural diplomacy entailed not only sending intellectuals and shows by Brazilian artists to Paraguay, but more subtle measures as well. Paraguayan artists and intellectuals were invited to Brazil to demonstrate genuine interest in their production and in Paraguayan culture more generally. Together, these acts were a way to show Paraguay that the time was right for true cultural exchange. The various means by which Brazilian cultural actors (critics, museums, biennials, etc.) recognized emerging Paraguayan artists in subsequent years were related, to varying degrees, to the strategies deployed by Brazilian cultural diplomacy. That by no means questions the genuine value of Paraguayan production from those years. In September 1953, some months before the opening of the second edition of the São Paulo Biennial, Josefina Plá and José Laterza Parodi travelled to that city at the invitation of the MAM-SP to exhibit their ceramics. The exhibition also included a major set of works by Julián de la Herrería. The positive review of the show published in the newspaper O Estado de São Paulo was reproduced in the Asunción press.

27 During her stay in São Paulo, Josefina Plá gave a series of talks on Radio Cultura (PRE 4) to make the work of Paraguayan artists (musicians, playwrights, writers, and visual artists) known in Brazil. At the invitation of the Escola da Arte, the aforementioned exhibition was held at the Biblioteca Municipal Castro Alves in Rio de Janeiro. On that occasion, Plá gave a talk on Paraguayan pottery. An article published in the Asunción press, "Demonstración a Josefina Plá," spoke of an "event in honor [of the Paraguayan 
artist] organized by a group of Brazilian intellectuals" (1953: 5). The event reflects how important Josefina Plá's activities in Brazil were to the Paraguayan intelligentsia.

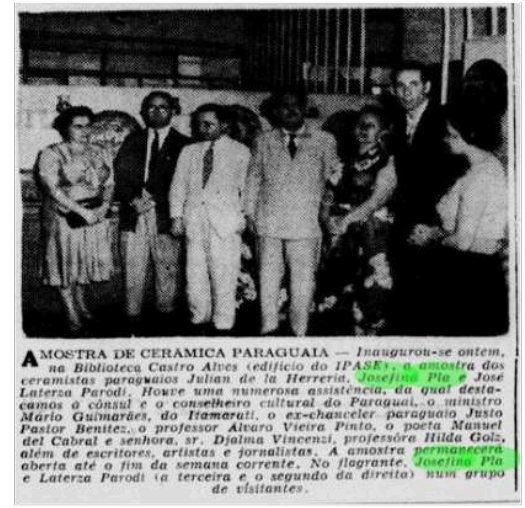

Figure 7: Josefina Plá and José Laterza Parodi in Rio de Janeiro, 1953 like Edith Jiménez and Hermann Guggiari, would be awarded scholarships by Itamaraty through the Brazilian Cultural Mission. Jiménez studied printmaking at the MAM-SP Escola de Artesanato initially in 1958, though the scholarship would be extended for two additional years, during which time she studied at the Gravura Studio founded by Livio Abramo and María Bonomi. In 1959 and 1960, Hermann Guggiari lived São Paulo and Rio de Janeiro.

\section{Dances and Dinners at the Casa Argentina, Culture in the Brazilian Cultural Mission: The Place of Paraguayan Modern Art in the Region}

In 1953, Paraguay, through the Brazilian Cultural Mission, was invited to participate in the São Paulo Biennial for the first time (the Biennial's second edition opened in December). ${ }^{3}$ The task of deciding who would participate in the Paraguayan representation fell on the Circulo de Artistas Plasticos of Paraguay, and it was cause for tension among members of the Circle. A dispute ensued between a small sector led by Josefina Plá that included olga Blinder, Lilí Del Mónico, and José Laterza Parodi. Their stated support of new art put them at odds with the more established figures in the Circle, namely Roberto Holden Jara (1900-1984), Jaime Bestard (1892-1965), and Pablo Alborno (1875-1958). Parenthetically, Olga Blinder-still at the beginning of her career 
-was not yet a member of the Circle, nor did she know Holden Jara, president of the organization (Goosen, 2004). ${ }^{4}$ That was undoubtedly one of the reasons Blinder's application to form part of the Paraguayan representation at the Biennial only heightened tension within the Circle. Also significant was the fact that some months before the opening of the Biennial, Josefina Plá and José Laterza Parodi had exhibited ceramics at the MAM-SP and in Rio de Janeiro. The exhibition was well received by Brazilian cultural critics and other cultural agents, which served to bolster Plá's side in the dispute. Ultimately, Blinder and Laterza Parodi's works did represent Paraguay at the Biennial, as did works by Pablo Alborno, Jaime Bestard, Alicia Bravard, Roberto Holden Jara, Edith Jiménez, Ofelia Echagüe Vera, Adam Kunos, and Vicente Pollarolo. The Biennial's catalogue text on the Paraguayan works-most likely written by poet and art critic Ramiro Domínguez-spoke of the presence of "veterans" as well as "young people."

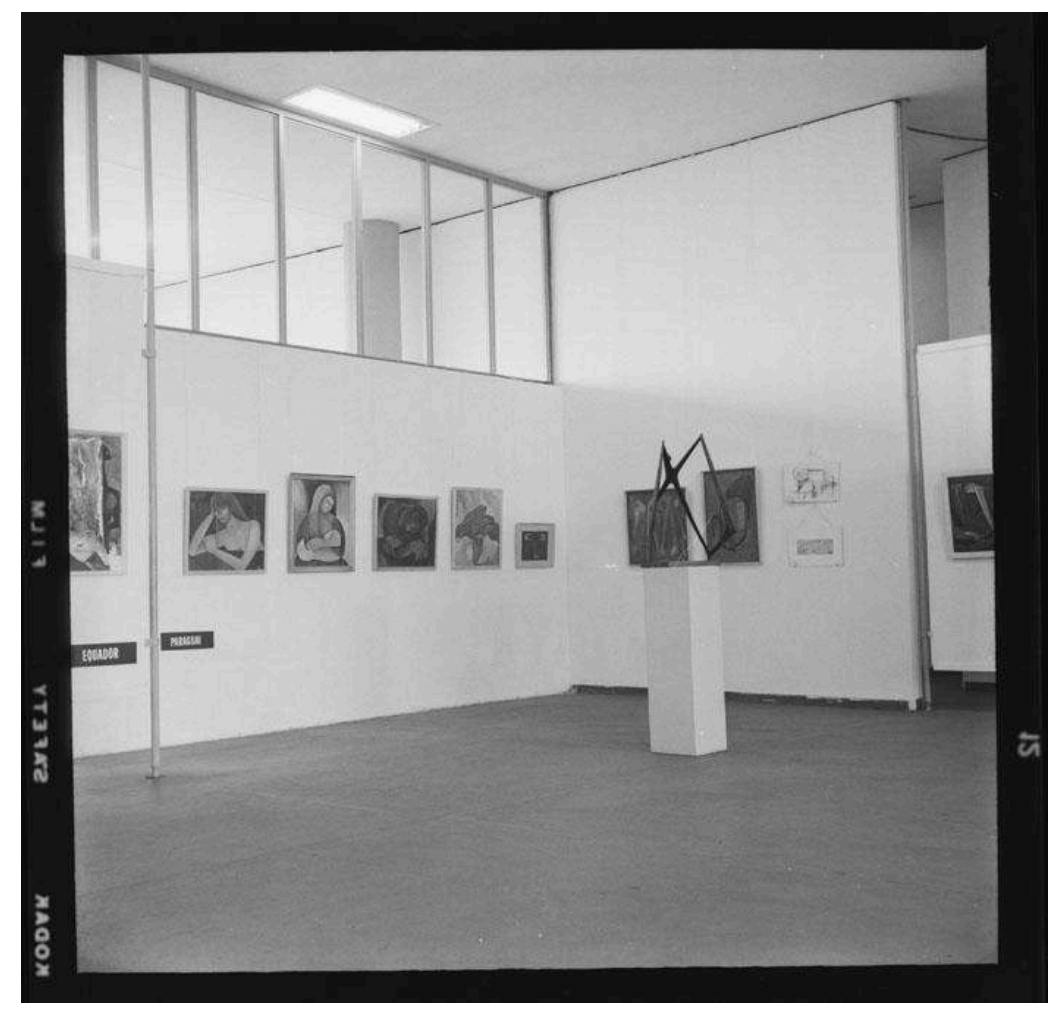

Figure 8: The Paraguay Exhibition, V São Paulo Biennial, São Paulo, 1959 


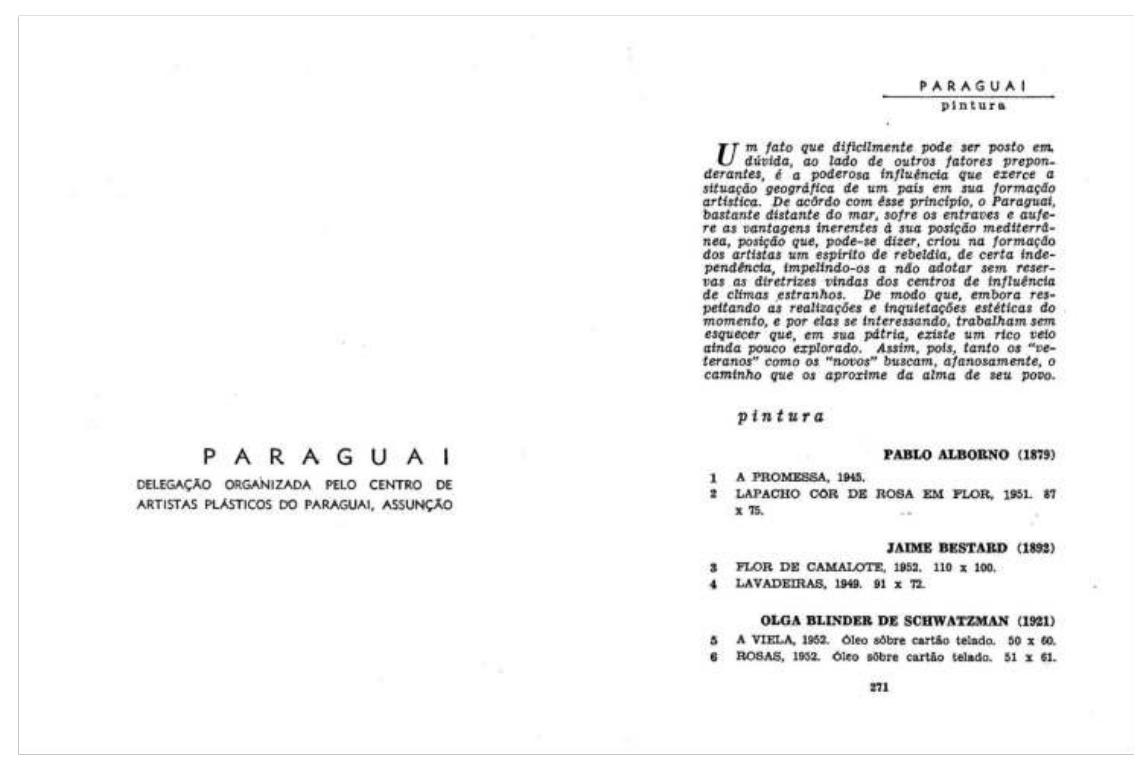

Figure 9: Text on the Paraguayan representation, Catalogue to the Second São Paulo Biennial, 1953

As a consequence of that dispute, the dissident sector of the Circle founded the Arte Nuevo group, and organized its first show: the First Week of Paraguayan Modern Art, held from July 17 to 24,1954 . In fact, two years earlier, in 1952, the members of what would become the Arte Nuevo group had issued a document that came to be known as the Manifiesto del Arte Moderno Paraguayo. The text speaks of the need to renew Paraguayan art. From August 18 to September 4, just one month after the First Week, works by the Arte Nuevo group's most active members (Blinder, Del Mónico, Plá, and Laterza), along with works by Julián de la Herrería, were exhibited at the Sociedad Argentina de Artistas Plásticos in Buenos Aires, a venue near Florida Street in downtown Buenos Aires. That was when Olga Blinder met influential Argentine art critic Jorge Romero Brest. The first recognition of the Arte Nuevo collective came from Buenos Aires, a city that was still a point of reference in the imaginary of Paraguayan elites. The institutional ties between Brazil and Paraguay, through the Brazilian Cultural Mission, would be decisive to positioning the modern art championed by the Arte Nuevo group.

In 1956, Livio Abramo (1903-1993), Brazilian master printer, arrived in Asunción at the invitation of the Cultural Mission. He, along with Oswaldo Goeldi and Carlos Oswald, constituted the first group of great modern printmakers in Brazil. It was with the arrival of Livio that the artistic-institutional exchanges fundamental to the regional insertion of modern art as envisioned by the Arte Nuevo group took on new weight. Livio created the el Taller de Grabado Julián de la Herrería, directed by olga Blinder, Lotte Schulz, and María Adela Solano López from 1956 to 1960. The Cultural Mission then helped form the Escolinha de Arte, founded by Augusto Rodrigues and based on the Herbert Read education through art method. Olga Blinder was in charge of the Escolinha. From the time of his first stay in Asunción, Livio Abramo was in close contact with the Paraguayan art scene, mainly through the Arte Nuevo group. In 1956, Blinder's 
paintings were featured in the group exhibition Retrospectiva de la Pintura Paraguaya, held in the gallery of the Sociedade de Arquitetos São Paulo. Shortly thereafter, her work was exhibited in the MAM-SP.

The Arte Nuevo group dominated the Paraguayan representation at the IV São Paulo Biennial held in 1957. Sculptures by two members of the group, Josefina Plá and José Laterza Parodi, were awarded the Arno Prize, the first international distinction ever given to modern art from Paraguay. The presence of Paraguayan art abroad would grow in subsequent years, as would recognition of it in the form of awards and distinctions. Paraguayan modern art would not truly consolidate until the sixties, however, as Paraguayan artistic languages were modernized and the process, begun the previous decade, of putting them in synch with regional production finished.

Years later, Olga Blinder would recall in an interview the Brazilian cultural presence in Paraguay in the fifties, and how it was much better coordinated than the Argentine presence. She gets at some key aspects of the times when she says:

-When you speak of your origins, you describe them as being very close to Argentina. But in terms of art, you say your tie to Brazil was stronger When my children were old enough for kindergarten, the model school was the one run by the Brazilian Cultural Mission, and I sent them there. That was when I became interested in education. As a mother, I started helping out at the kindergarten. Then Augusto Rodrigues arrived, and he told us about education through art. Then Livio Abramo came, and he taught us about printmaking. I would say there were four Brazilians who greatly influenced Paraguayan art: Livio Abramo in printmaking, Augusto Rodrigues in art education, João Rossi in painting, and Saturnino Brito in architecture. They were instrumental to a new vision of art in Paraguay. For those reasons, I was close to the Brazilians. The Argentines didn't do any of that; they had the Casa Argentina with its dances and dinners, while the Brazilians took care of culture. (Apud Goosen, 2004: 202)

\section{Conclusions}

Although as early as the nineteen-twenties, some Paraguayan artists produced patently modern works-consider Andrés Campos Cervera-those experiences were fragmentary and scattered. Modern art failed to take root, and the local art scene was isolated from international trends. It was not until the second half of the fifties that a combination of projects, most of them spearheaded by the Arte Nuevo group and the Brazilian Cultural Mission-a fundamental instrument of Brazilian cultural diplomacy as it vied with Argentina for hegemony-lay the foundations for modern art from Paraguay and its insertion in the region. Significant to that process as well was the new interest in Brazil on the part Paraguayan foreign policy. Though often considered the launching of modern art in Paraguay, the First Week of Paraguayan Modern Art (1954) was actually a reworking of earlier impulses.

The sixties witnessed the emergence of Los Novísimos, a group that challenged, in clear avant-garde spirit, the Arte Nuevo group's hegemony in the emerging field of modern art. Formed by José Antonio Pratt-Mayans (b.1943), Enrique Careaga (1944-2014), William Riquelme (b.1944), and Ángel Yegros (b.1943), this group "set out to constitute a creative alternative based on generational rupture, international openness, and radical innovation of expressive media" (Escobar, 2011: 383). The formal and informal networks that linked artists and strategies starting in the second half of the fifties 
produced a more complex cultural map that went beyond the fragile frameworks of the local scene and national history.

\section{BIBLIOGRAPHY}

BLINDER, Olga (1985). 1956-1985.Comentarios. Pintura-Dibujo-Fotografía-Grabado. Asunción, Ediciones IDAP.

BLINDER, Olga (1997). Arte actual en el Paraguay. 1900-1995. Asunción, Editorial Don Bosco. BLINDER, Olga and Ticio Escobar (2000). Caminos de la línea. Catálogo de muestra. Asunción, Arte Nuevo.

CAPDEVILA, Luc (2010). Una guerra total: Paraguay, 1864-1870. Ensayo de historia del tiempo presente. Buenos Aires, CEADUC / Editorial SB.

CENTURIÓN MORÍNIGO, Ubaldo (1996). Josefina Plá y el periodismo paraguayo. Asunción, Edipar. Demostración a Josefina Plá. (September 2, 1953). La Tribuna, p. 5.

ECHAURI DE MUXFELD, María Gloria (2012). Livio Abramo: su aporte a las artes visuales del Paraguay (1956-1992). Asunción, FONDEC.

ESCOBAR, Ticio (2007). Una interpretación de las Artes Visuales en el Paraguay, Asunción, Servilibro.

ESCOBAR, Ticio (2011). "Consideraciones sobre el arte desde la guerra contra la Triple Alianza" in Telesca, Ignacio (ed.). Historia del Paraguay. Asunción: Santillana, pp. 375-390.

FERNANDEZ, Miguel Ángel (July 18, 1954). Julián de la Herrería. Una obra en fecunda prolongación. La Tribuna, p. 5.

FOSTER, Hal (2001). El retorno de lo real. Madrid, Ediciones Akal. (English title: The Return of the Real)

GARCÍA, María Amalia (2011). El arte abstracto: intercambios culturales entre Argentina y Brasil, Buenos Aires, Siglo Veintiuno Editores. (English title: Abstract Crossing: Cultural Exchange between Argentina and Brazil)

GIUNTA, Andrea (2004). Vanguardia, internacionalismo y política. Arte Argentino en los años sesenta, Buenos Aires, Paidós. (English title: Avant-Garde, Internationalism, and Politics. Argentine Art in the Sixties)

GOOSSEN,Teresa (2004). Olga Blinder. Una biografía, Asunción, Goossen libros.

HEINICH, Nathalie (2010). La sociología del arte. Buenos Aires, Nueva Visión.

La exposición en la Calle Palma. (July 20, 1954). La Tribuna, p. 6.

MORA, Frank O (1993). La política exterior de Paraguay (1811-1989). Asunción, Centro Paraguayo de Estudios Sociológicos / Ediciones y Arte Editora. 
Muestra inaugurada. (October 24, 1953). La Tribuna, p.5.

NEPOMUCENO, Maria Margarida Cintra (2010). Lívio Abramo no Paraguai. Entretecendo culturas [online]. São Paulo: Integração da América Latina, Universidade de São Paulo. Dissertação de Mestrado em Integração da América Latina. [last visted: 05-18-2013]. Available at:<http:// www.teses.usp.br/teses/disponiveis/84/84131/tde-18122012-105632/>.

PLÁ, Josefina (1992). Obras Completas I. Historia Cultural. Asunción, RP Ediciones / Instituto de Cooperación Iberoamericana.

PLÁ, Josefina (n.d).Obras Completas III. Historia Cultural. Asunción, RP Ediciones / Instituto de Cooperación Iberoamericana.

PLÁ, Josefina (n.d.).Obras Completas IV. Historia Cultural. Asunción, RP Ediciones / Instituto de Cooperación Iberoamericana.

REITER CHEDID, Daniele (2010). Aproximação Brasil-Paraguai: A Missão. Dourados, Dissertação, Faculdade de Ciências Humanas da Universidade Federal da Grande Dourados (UFGD), Mestrado em História.

RODRÍGUEZ-ALCALÁ, Hugo (1971). Historia de la Literatura Paraguaya. Asunción, Colegio de San José.

RODRÍGUEZ-ALCALÁ, Javier (2001). Edith Jiménez. Retrospectiva: Obra Gráfica. Exhibition catalogue, Galería Livio Abramo of the Brazilian Embassy's Cultural Center, Asunción.

RODRÍGUEZ-ALCALÁ, Javier (2008) “Notas para una periodización contextual” in Hermann Guggiari, book-catalogue, Asunción, FONDEC/Asociación CulturalComuneros.

RODRÍGUEZ-ALCALÁ, Javier (2009) “Reidy en Cachinga: De la política del café con leche a la geopolítica del Hormigón Armado" in Irina Rivero and Rossana Delpino, Colegio Experimental Paraguay-Brasil. Obra de Affonso Eduardo Reidy, Asunción, ArteNuevo.

RODRÍGUEZ-ALCALÁ, Javier (2010) “Arte Nuevo y la reinvención del j(f)uego,” AICA-PY. Revista de arte / cultura. Número 2/3, Asunción, Fondec.

RUIZ DIAZ, Amalia (2004). Murales de Asunción. Asunción, FONDEC.

RUIZ DIAZ, Amalia (2009) Jaime Bestard: arte y dignidad. Asunción, FONDEC.

TAVARES DE ARAÚJO, Olívio (2001). "Livio Abramo, la ética y la revelación de lo visible" in Livio Abramo: 133 Obras restauradas. Catalogue of works, Asunción, Arte Nuevo.

\section{ENDNOTES}

1. On the cultural disputes between Brazil and Argentina, this work looks to María Amalia García's valuable contribution (El arte abstracto: Intercambios culturales entre Argentina y Brasil. Siglo Veintiuno Editores, 2011). My understanding of the minutiae of the Itamaraty and the role of the Brazilian Cultural Mission in Paraguay was furthered by the dissertations written by Daniele Reiter Chedid (Aproximación Brasil-Paraguay: La Misión for the History Department. School of Human Sciences, Universidade Federal da Grande Dourados - UFDG, 2010) and María Margarida Cintra Nepomuceno (Lívio Abramo no Paraguai. Entretecendo culturas. São Paulo: Integração da América Latina, Universidade de São Paulo. Dissertação de Mestrado em Integração da América Latina, 2010). (English 
title of García's book: Abstract Crossings:Cultural Exchanges between Argentina and Brazil)

2. Born in the Canary Islands in 1903, Josefina Plá moved to Paraguay in 1926 with her husband, artist Julián de la Herrería. She worked intensively as a writer and a visual artist, and as a journalist and art critic. Along with Hérib Campos Cervera and Augusto Roa Bastos, Julio Correa, Óscar Ferreiro, Elvio Romero, Hugo Rodríguez-Alcalá, and Ezequiel González Alsina (all of them members of the Grupo del Cuarenta), she advocated a deep change in Paraguayan literature in the forties in order to bring avantgarde visions to the country (Rodríguez-Alcalá, 1971).

3. The Biennial's second edition took place in the Parque do Ibirapuera, which had recently been built to commemorate the four hundredth anniversary of the founding of São Paulo. The park was designed by Oscar Niemeyer (1907-2012) and Burle Marx (1909-1994). This edition of the Biennial came to be known as the Guernica Biennial because of the presence of Picasso's celebrated painting (1937).

4. Her first solo show had been held at the Paraguayan-American Cultural Center in September 1952. That was where she met Josefina Plá and, through her, she began to see Lilí Del Mónico and José Laterza Parodi, regulars at the Plá home, more often. (Goosen, 2004)

\section{ABSTRACTS}

During a relatively brief period-from the mid-nineteen-fifties to the early sixties-Paraguayan artistic production, which had been marked by inertia and chronic isolation, underwent an unusual process of renewal as it found a place in new regional artistic circuits. The Brazilian Cultural Mission, which strategically pursued rapprochement as it vied with Argentina for hegemony, coupled with a shift in Paraguayan foreign policy as the Adolfo Stroessner regime opened up to the east, favored, on a structural level, the insertion of Paraguayan modern art in the regional milieu. The Asunción-based Arte Nuevo group was central to that process.

En el curso de un arco temporal relativamente breve -desde mediados de 1950 a principios de 1960-, la producción plástica paraguaya, marcada por la inercia y el aislamiento crónico, experimentará un inusitado proceso de renovación y de inserción en los nuevos circuitos artísticos regionales. Las estrategias de aproximación al Paraguay impulsadas por la Misión Cultural Brasileña, en el marco de una disputa por la hegemonía con la Argentina, y el giro de la política exterior paraguaya en la búsqueda de una salida al Este, con Stroessner, crearon coyunturalmente un marco favorable para la afirmación e inscripción de la plástica moderna paraguaya en el ámbito regional. El grupo Arte Nuevo, será un protagonista central de este proceso.

Dans un laps de temps relativement court -allant du milieu des années 50 au début des années 60-, la production plastique paraguayenne, marquée par l'inertie et l'isolement chronique, connaîtra un processus inhabituel de renouvellement et d'insertion dans les nouveaux circuits artistiques régionaux. Les stratégies d'approche du Paraguay préconisées par la Misión Cultural Brasileña, dans le cadre d'un conflit sur l'hégémonie avec l'Argentine, et le tournant de la politique étrangère paraguayenne dans la recherche d'une sortie à l'Est avec Adolfo Stroessner ont créé un cadre favorable à l'affirmation et à l'inscription du plastique paraguayen moderne dans le champ d'application régional. Le groupe Arte nuevo basé à Asuncion sera l'un des principaux protagonistes de ce processus. 
INDEX

Palabras claves: Arte moderno paraguayo, Grupo Arte Nuevo, Misión Cultural Brasileña, Josefina Plá, Olga Blinder, Bienal de São Paulo.

Mots-clés: Art moderne paraguayen, Groupe Arte Nuevo, Mission culturelle brésilienne. Josefina Plá, Olga Blinder, Biennale de São Paulo.

Keywords: Paraguayan modern art, Arte Nuevo group, Brazilian Cultural Mission, Josefina Plá, Olga Blinder, São Paulo Biennial.

\section{AUTHORS}

\section{CHARLES QUEVEDO.}

Charles Quevedo has an MA in social sciences from the Facultad Latinoamericana de Ciencias Sociales (FLACSO). He was a fellow at the "Seminar Identities in Transit," (2004-2005) Centro de Artes Visuales/Museo del Barro and Rockefeller Foundation. He is the coordinator of the "Intellectual and Political" Working Group of the Consejo Latinoamericano de Ciencias Sociales (CLACSO). 